\title{
Internationalization process on the example of LVMH
}

Karolina Płoneczka*

Internationalization can be seen as a process of making a company's business international, branching out and moving from its local market to foreign markets. In today's world, more and more brands are 'born global', so this process cannot be applied to them. However, there are still companies, for example on the luxury goods market, that have the potential for internationalization, but they remain local till one of the big players, such as LVMH or Kering, discovers them, makes them a part of an international conglomerate and presents them to the wider public.

Such a situation as described above is often used when these big players want to enter a new market or branch and use a company that already runs a business there to get the knowledge about this market to expand there, including their other businesses. It is worth remembering that the luxury goods market is a hermetic one that is also monopolized by the conglomerates, so it is really difficult for smaller companies to survive. The goal of this article is to briefly present the internationalization phenomenon and show it on the example of LVMH on the Asian market, with special attention paid to the Chinese luxury market.

\section{Internationalization}

Internationalization can be defined in many ways, the most popular definition being the one presented by Johanson and Vahlne in 1977. According to them, "Internationalization is any activity undertaken abroad" (Johanson, Vahlne 1977, pp. 22-23). A very similar definition is presented in the Business Dictionary: "The growing tendency of corporations to operate across national boundaries" (Busi-

\footnotetext{
* Karolina Płoneczka - M.Sc., Wroclaw University of Economics, Faculty of Economic Sceinces, Department of International Economic Relations, karolina.ploneczka@ue.wroc.pl.
} 
ness Dictionary). Both definitions are very general and, according to them, selling goods abroad, for example, should be treated as the internationalization of the company.

A more comprehensive definition was presented by Beamish in 1990: "internationalization is the process by which firms both increase their awareness of the direct and indirect influences of international transactions on their future, and establish and conduct transactions with other countries" (Beamish 1990, p.77). This definition shows that learning is an important aspect is of the company when it expands to other markets along with choosing the proper market and the mode of entry. For example, the internationalization process of the company can begin with foreign sourcing or countertrade, later evolving into a joint-venture or creating a foreign affiliate (Buckley, Ghauri 1998, p. 115).

Internationalization can be observed from 3 perspectives:

1) the process approach - where internationalization is analysed through the prism of its phases and is understood as the growth of the company from a national business through an international one to finally becoming a global business;

2) the static approach - where internationalization is analyzed as an institutional phenomenon that is characterized by the level of company's independence in strategy realization and using different indexes that describe the intensity of the company's internationalization;

3) the behavioral approach - internationalization is examined through the behavior of international companies' management; every company that undertakes activities abroad has some role models that are based mainly on the management's view on the external environment of the company (Rymarczyk 2004, pp.19-31).

In the case of internationalization, a company's motives are also important. The following motives can be distinguished:

1) market motives - connected with the opening of new markets, but also with being a leader on already penetrated ones;

2) cost motives - crucial in the case of many firms, they help to increase revenue and decrease production costs, their main goal being to enhance the profitability of the business;

3 ) supply motives - are connected with the import of production factors in situations when they are lacking in the home country or their price is much higher, for example, lower research costs or cheaper access to resources;

4) political motives - here we can classify all actions taken by the home government as well as that of the host country, such as tax incentives, political stability and credit guarantees among others (Walas-Trębacz 2006, pp. 184-186). 


\section{Conventional models of internationalization}

There are two main models of internationalization that were created in the 1970s. The first one is the Uppsala model (U-model), created in 1977 by Johanson and Widersheim-Paul, and later developed by Vahlne. They observed certain conditions that are fulfilled by companies which begin internationalization process:

1) the company is successful in the internal market and expansion is a consequence of many decisions undertaken;

2) the first expansion is directed towards close markets; later, more distant markets are taken into consideration;

3) when entering foreign markets, companies begin with exports and later engage in more complex activities (Gorynia 2007, pp. 63-63).

The most important assumption of the Uppsala model is that the internationalization process has a sequential character. According to Johanson and Widersheim-Paul, there are 4 phases of internationalization: irregular export, export activities using intermediaries, creating a trading affiliate, and the last one is creating a production affiliate (Johanson, Vahlne 1993, p. 45).

The second group of models (I-models) is based on innovation, the most popular ones being created by Cavusgil and Korth. These models perceive internationalization from the innovation perspective. In Cavusgil's model, there are 3 stages of internationalization: experimental involvement, active involvement and committed involvement. In the first stage, companies' actions on a foreign market are somewhat spontaneous and the companies are oriented towards short-term profits on close markets. In the next stage, export is systematic, but export markets are still limited. In the last phase, the company looks for more active forms of international involvement such as production affiliates (Cavusgil 1984, pp. 195-208). In Korth's model, there are 4 degrees of internationalization: $1^{\text {st }}$ degree internationalization is a passive one that includes an intermediary in international relations; $2^{\text {nd }}$ degree internationalization is an active approach that includes the creation of the company's own import or export department; $3^{\text {rd }}$ degree internationalization is very active engagement in international business and includes the creation of a foreign affiliate; $4^{\text {th }}$ degree is the creation of a global structure (Korth 1985).

\section{Other models of internationalization}

Besides the conventional models of internationalization, other approaches include the transactional cost model, the eclectic theory of international production, and network theory, among others. Two of the most popular models are briefly described below:

1) network model - in this model, all actors are linked to each other thanks to different types of relationships and interactions that occur; all actors are independent and can create or break the relationships; the basic 
assumption is that the company is dependent on the resources that are controlled by other firms; a network position is required to gain external resources; the relationships existing in a home country network can be used as a bridge to networks in other countries; they can be the first step to expanding internationally or they can be treated as a way to enter new markets (Hollensen 2008, pp. 61-63);

2) born global - "a firm that, from its inception, pursues a vision of becoming global and globalizes rapidly without any preceding long-term domestic or internationalization period" (Oviatt, McDougall 1994, p. 48); from the beginning, they have a global geographic scope, and both a fast information exchange and proper infrastructure are needed; these are mostly tech-industry companies with entrepreneurial visionaries in charge; in recent years, the concept of the 'born-again global firm' has been proposed. It is connected with firms that were focused on their domestic markets but now embrace rapid and dedicated internationalization (Bell et al. 2001, pp. 173-190).

For the purpose of this article, the conventional models of internationalization were discussed more widely due to the better applicability in the case of the early development stage of LVMH.

\section{LVMH}

LVMH Moët Hennessy Louis Vuitton SE, usually shortened to LVMH, is an international company specializing in the trade of luxury goods. It is the leader in the luxury goods market as far as the total number of owned brands and total value of sales achieved yearly are concerned. In today's form, LVMH was established in 1987 and since 1989, LVMH's CEO is Bernard Arnault, responsible for the successful development of the firm (Forbes).

LVMH can be described as a transnational corporation because it has operations concentrated in several branches located all over the world. It has affiliates that are controlled by a parent company; however, the most important aspect has always been its long-term vision. Among other things, it also uses foreign direct investment as a way of developing new projects and entering new markets.

\section{A brief history of Louis Vuitton}

The Louis Vuitton company was established in 1854, when its founder and owner, Louis Vuitton, opened his first packing and trunk-making business in Paris. In a short time, he gained a reputation as a master of luggage-making and he developed his business by opening his workshops in Asnières, near Paris. In 1885, the internationalization process started when the first foreign store was opened in 
London. Louis Vuitton died in 1888, leaving the business to his son Georges, who decided to build a sales network abroad. The company started building its sales network from New York and Philadelphia, followed by Boston, Chicago and San Francisco, and by the beginning of $20^{\text {th }}$ century it was also present in Brussels, Nice, Buenos Aires, Bangkok and Montreal (Reference for Business).

In 1977, Louis Vuitton S.A. was created, followed by a huge international expansion including the opening of new stores all over the world, focusing on the Asian market and building a strong distribution network. All these actions resulted in sales increasing from 20 million USD in 1977 to nearly 1 billion USD in 1987. In 1984, the company started to sell stock publicly through exchanges in Paris and New York (Reference for Business).

\section{A brief history of Moët et Chandon}

The company Moët et Cie was established in 1743 (LVMH) by Claude Moët near Epernay in the Champagne region in France. In 1750, the company started to sell champagne abroad to Germany and Spain, as well as Eastern Europe and America. Further development of the company resulted in a remarkable rise in annual sales that in 1880 reached 2.5 million bottles.

In the late 1920s, the brand Dom Pérignon was introduced, which still remains one of the most expensive and at the same time the most successful premium champagne on the market. In the $20^{\text {th }}$ century, after the Second World War, they focused on acquiring their competitors and expanding operations outside the champagne business. In 1971, Moët et Chandon merged with Jas Hennessy \& Company, France's second largest cognac producer, and changed its name to Moët-Hennessy.

In the 1970s, the diversification of the company started. The firm acquired Roc - the French cosmetic producer, Delbard - the rose company, and Armstrong Nurseries of Ontario - the largest American farm of rosebushes. Thanks to the last two acquisitions, Moët-Hennessy became the largest rose producer in the world. In 1973, the Domaine Chandon winery in Napa Valley was opened, and soon afterwards Moët-Hennessy acquired its American sales agent - Schieffelin \& Company (Reference for Business).

\section{Establishing LVMH}

In 1987, a merger worth 4.0 billion dollars was carried out between Louis Vuitton and Moët-Hennessy. The newly formed holding company was named Moët-Hennessy Louis Vuitton (LVMH). The firm instantly became the biggest player in the luxury goods sector. After the merger, the autonomy of both companies as regards management and subsidiaries was preserved (Funding Universe).

Since the establishment of LVMH, the company has developed itself mainly by acquiring new firms from the luxury sector, but also entering new markets 
by opening stores there, for example, the Louis Vuitton boutique in Warsaw, or investing in companies from new branches that are not always connected with luxury goods market, e.g. EDUN, the fashion brand co-created by Bono and Alison Hewson. The main market that the company is focusing its effort on is Asia, which generates most of the company's revenue (Picture 1).

Picture 1. LVMH percentage revenues by region in the first half of 2017

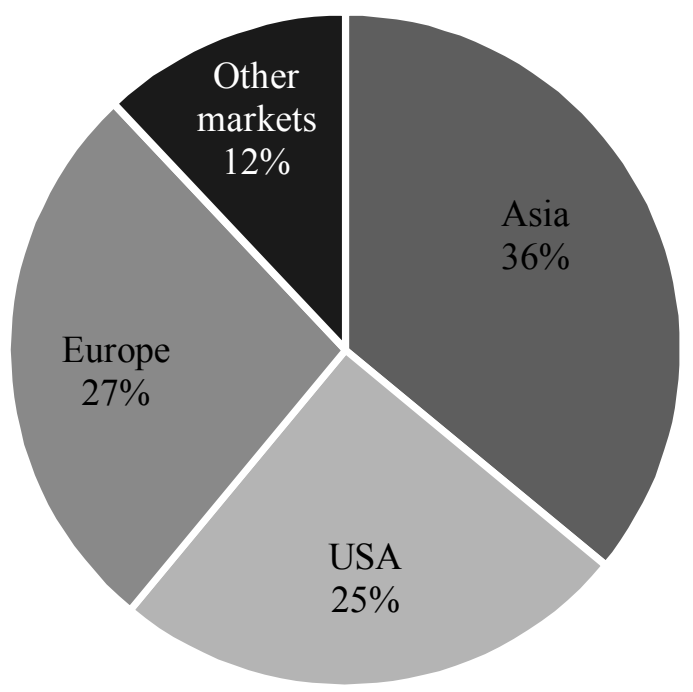

Source: own elaboration based on LVMH Interim Financial Report, 30th June 2017, p. 2.

LVMH's internationalization strategy is not easy to define because nowadays the conglomerate is huge and has a wide portfolio of brands from different branches. The company is mostly focused on acquiring brands with potential from the fashion industry. These are brands created by a new generation of designers and should be internationally successful in a few years. LVMH is also expanding its Wines \& Spirits division by adding new brands from different world regions. Moreover, the company is expanding its portfolio by engaging in projects such as the Cheval Blanc ski resort in Courchevel, France (Passariello 2010), which is the first hotel in the planned luxury hotel chain, or making its first step in the upper end of food business by purchasing a majority stake in Italian Pasticceria Confetteria Cova Srl (Diderich 2013). It can be observed that the company's focus is on choosing the finest and most promising brands and adding them to its portfolio. What is more, when entering a new market, the conglomerate also looks for potential firms that can be acquired. 


\section{LVMH's development on the Chinese market}

In 2008, first Chinese alcoholic beverage brand, Wen Jun, was added to the brand portfolio by the acquisition of a 55.0\% share (LVMH). In 2010, LVMH created an Asian branch called L Capital Asia, the largest consumer-focused private equity firm in Asia, with its headquarters in Singapore and regional offices in Hong Kong, Shanghai, Mumbai and Melbourne. In 2016, after a merger with the Catterton company, it changed its name to L Catterton Asia (L Catterton Asia).

The focus on the Asian market is visible in LVMH's investments: in 2010, a joint venture with the Koh family of Singapore began, and the result was a takeover of a $51.0 \%$ stake in Heng Long Tannery, one of the most important crocodile skin suppliers in the world (Sor 2014). The following year, LVMH purchased a $20.0 \%$ stake in Charles \& Keith, an Asian company specializing in women's accessories and footwear (Chan 2011). In 2014, it invested in a 51.0\% stake of the Singaporean nightclub holding company, Ku De Ta, and purchased Crystal Jade, a restaurant chain (Sor 2014). Current investments include, among others:

1) the Asiaray Media Group, which operates in China and Hong Kong. It concentrates on advertising in airports, metro lines, and billboards and building solutions, as well as providing design, consultancy, construction, and maintenance services (Bloomberg);

2) Clio Cosmetics - a Korean cosmetics brand for women;

3) Dr. Wu Skin Care - Taiwan's number one medical skin care brand;

4) Marubi - a Chinese cosmetic brand (L Catterton Asia).

It is also worth indicating that, during a one year period, LVMH increased the number of shops in Asia from 1348 in 2016 (LVMH 2016, p. 2) to 1423 in the first half of 2017 (LVMH 2017, p. 2). What also highlights the importance of the Asian market is the fact that, for the first time, the venue for Louis Vuitton's Cruise collection took place in the Miho Museum near Kyoto (LVMH 2017, p. 11).

It seems natural for LVMH that its main target market is China, as it is connected with:

1) growth in disposable income, which is expected to continue in the next few years;

2) the growing number of "upper-middle-class" in Chinese society;

3) the increasing number of millionaires and super-rich individuals in China;

4) the rising demand for luxury goods in smaller cities (population less than 1.5 million) (Fung Business Intelligence Centre 2015, pp. 20-23).

In recent years, the luxury goods market in China has grown rapidly, from 9.2 billion EUR in 2009 to 28.0 billion EUR in 2015. Forecasts for the future are optimistic. The market will continue to grow and will become a vital source of sales of luxury goods; by 2020, its estimated value should reach 74 billion EUR (Statista). 
LVMH's position on the Chinese market is strong, thanks to its main brand Louis Vuitton, which is the most recognized luxury brand in China. The company has 47 boutiques there, located mostly in the first tier cities (large metropolises with a huge economic, cultural and political influence), e.g., Shanghai and Beijing. Instead of spreading the network, Louis Vuitton wants to invest in existing stores to enhance the level of experience that it offers its customers (Anderlini 2015). Bernard Arnault, CEO of LVMH, said, "You have to be optimistic in the long term and pessimistic in the short term. That allows you to prepare for the worst." So, LVMH's strategy in China will remain flexible, and when it makes sense the company will close stores there, but it is clear that, for the foreseeable future, it will open new ones (Bain 2016).

There are three strong trends that companies should take into consideration during successful strategy creation on Asian markets:

1) delivery of an exceptional in-store experience - this is the most important factor that influences purchase decisions, so the salespeople should be well-trained to ensure this unique experience to the customers, which fully corresponds with the Louis Vuitton strategy in China;

2) power of the Internet - it has become the second most important consumer touch point, especially for luxury categories like clothes; to be successful, sophisticated web strategies will need to be created with the help of local media agencies that know the market well;

3) opportunity to share in the rich brand heritage - an increasing number of Chinese customers pay attention to brand heritage and history, so brands have started to use them as a promotion method, but they should also take into consideration local tastes, because one-third of Chinese luxury consumers said that they are willing to buy products designed especially for their market (Atsmon et al. 2011).

\section{Conclusion}

Internationalization can be simply described as any activity undertaken by a company to develop its business and presence on the foreign market. It might only be the export of a company's products, but it can also be a joint-venture with local producers or the creation of an affiliate in a foreign country. Internationalization can be described as a process, using a static or behavioral approach. The main motives of internationalization are cost motives, but there are also market motives, supply motives and political motives.

Both presented models see internationalization as a process that consists of several stages. It is difficult to fit only one model to LVMH's activities because the company created its own unique model that is successful and possesses elements of the Uppsala model as well as both innovation models. LVMH, since 
its inception, has used internationalization as a way to enter new markets and expand its businesses globally. It is extremely difficult to assign only one internationalization model to LVMH. The company uses chosen elements from various models. Besides the conventional models, others, such as the transaction cost model, network model or 'born-global', can be observed.

LVMH is focused on the Asian market, which is shown by multiple investments there and the opening of numerous shops there. The main market for the company is China. The Chinese luxury market is extremely dynamic, and consumers have become more sophisticated and demanding. There is a new trend that people are more likely to purchase low-key, unique products instead of products with conspicuous logos. Chinese consumers, especially those from the younger generation, care more about brand history, heritage and culture, because through unique and exclusive products they want to show their taste and sophistication. The brand heritage concept corresponds perfectly with the marketing strategy of many brands in LVMH's portfolio. The Chinese market is dominated by foreign luxury brands, but domestic ones are gaining popularity, especially those which emphasize local craftsmanship and culture. This may be a great opportunity for LVMH to find new local partners on the market and start to invest in local niche brands that are totally unknown in Europe or even in Asia (Fung Business Intelligence Centre 2015, pp. 25-32).

The Internationalization process in the case of LVMH is a complex one and its strategy will evolve with changing market trends and new customer needs. There are several factors that should be taken into consideration, one of them being the fast-developing e-commerce market, also in the case of the luxury goods sector. To keep up with the newest market trends, as well as to stay in touch with clients and potential consumers, besides creating an advanced marketing strategy, the company should also create a sophisticated web strategy that involves mainly social media, which is the easiest way to attract millennials.

\section{Bibliography}

Anderlini J. (2015), Louis Vuitton stung by China luxury woes, ft.com, https:// www.ft.com/content/51e1dc9e-8c33-11e5-a549-b89a1dfede9b (accessed: 10.09.2017).

Atsmon Y., Dixit V., Wu C. (2011), Tapping China's luxury-goods market, mckinsey.com, www.mckinsey.com/business-functions/marketing-and-sales/ourinsights/tapping-chinas-luxury-goods-market (accessed: 14.11.2017).

Bain M. (2016), The world's biggest luxury company isn't worried about China, qz.com, https://qz.com/608970/the-worlds-biggest-luxury-company-isntworried-about-china/ (accessed: 10.09.2017). 
Beamish, P.W. (1990), The Internationalisation Process for Smaller Ontario Firms: A Research Agenda [in:] A.M. Rugman (ed.), Research in Global Strategic Management - International Business Research for the TwentyFirst Century: Canada's New Research Agenda, JAI Press Inc., Greenwich.

Bell J., McNaughton R., Young S. (2001), Born-again global firms: an extension to the born global phenomenon, Journal of International Management, Vol. 7(3), pp. 173-190.

Bloomberg, Company Overview of Asiaray Media Group Limited, www.bloomberg. $\mathrm{com} / \mathrm{research} /$ stocks/private/snapshot.asp?privcapid=268053991 (accessed: 10.09.2017).

Buckley P.J., Ghauri P.N. (1998), The Internationalization of the Firm, $2^{\text {nd }}$ Edition, Cengage Learning EMEA, Hampshire.

Cavusgil S.T. (1984), Differences Among Exporting Firms Based on Their Degree of Internationalization, Journal of Business Research, Vol. 12 (2), pp. 195-208.

Chan R. (2011), Charles \& Keith Goes Global with LVMH Tie-Up, jakartaglobe.id, http://jakartaglobe.id/archive/charles-keith-goes-global-with-lvmh-tie-up/ (accessed: 10.09.2017).

Diderich J. (2013), Fashion Scoops, Women's Wear Daily, 28.06.2013, p. 11-1.

Forbes, Bernard Arnault \& family, www.forbes.com/profile/bernard-arnault (accessed: 06.08.2017).

Funding Universe, LVMH Moët Hennessy Louis Vuitton SA History, www.fundinguniverse.com/company-histories/lvmh-mo\%C3\%ABt-hennessy-louis-vuitton-sa-history (accessed: 06.08.2017).

Fung Business Intelligence Centre (2015), Luxury market in China.

Gorynia M. (2007), Strategie zagranicznej ekspansji przedsiębiorstw, PWE, Warszawa. Hollensen S. (2008), Essentials of Global Marketing, $1^{\text {st }}$ edition, Pearson Education Limited, Essex.

Johanson J., Vahlne J.E. (1977), The Internationalization Process of the firm - A Model of Knowledge Development and Increasing Commitments, Journal of International Business Studies, Vol. 8, pp. 23-32.

Johanson J., Vahlne J.E (1993), Management of Internationalization [in:] L. Zan, S. Zambon, A.M. Pettigrew (eds.), Perspectives on Strategic Change, Kluwer Academic Publishers, Boston/Dordrecht/London.

Korth Ch.M. (1985) International Business. Environment and Management, $2^{\text {nd }}$ edition, EnglewoodCliffs N.J. [in:] M. Gorynia (ed.), Strategie zagranicznej ekspansji przedsiębiorstw, 2007, PWE, Warszawa.

L Catterton Asia, http://lcattertonasia.com/ (accessed: 10.09.2017).

LVMH (2016), Interim Financial Report

LVMH (2017), Interim Financial Report

LVMH, www.lvmh.com (accessed: 10.09.2017).

Oviatt B., McDougall P. (1994) Towards a theory of international new ventures, Journal of International Business Studies, Vol. 25(1), pp. 45-64. 
Passariello C. (2010), LVMH Extends Posh Label to New Luxury Resorts, www.wsj. com/articles/SB10001424052702304198004575171680599417158 (accessed: 10.09.2017).

Reference for Business, LVMH Moët Hennessy Louis Vuitton Sa - Company Profile, Information, Business Description, History, Background Information on LVMH Moët Hennessy Louis Vuitton Sa, www.referenceforbusiness.com/history2/1/Lvmh-Mo-t-Hennessy-Louis-Vuitton-Sa.html (accessed: 06.08.2017).

Rymarczyk J.(2004), Internacjonalizacja i globalizacja przedsiębiorstwa, PWE, Warszawa.

Statista, Sales of luxury goods in China from 2010 to 2020 (in billion euros), www.statista.com/statistics/280369/projected-luxury-goods-revenue-in-china (accessed: 10.09.2017).

Sor O. (2014), 5 Singapore businesses acquired by French luxury group LVMH, www.herworldplus.com, www.herworldplus.com/shopping/updates/5-singapore-businesses-acquired-french-luxury-group-lvmh (accessed: 10.09.2017).

Walas-Trębacz J. (2006), Sposoby wejścia przedsiębiorstw na rynki zagraniczne, Zeszyty Naukowe Akademii Ekonomicznej w Krakowie, Vol. 700, pp. 181-198.

\section{Summary}

Internationalization is a process commonly used by companies to expand their business. It can be understood as entering new foreign markets by using different methods such as joint-venture, greenfield investments, but also simply selling the products abroad. There are two main models of internationalization: the Uppsala model and models based on innovation. LVMH is an international luxury goods conglomerate that since the beginning of its existence has used internationalization as a way of entering new markets and expanding its businesses even more.

Now, their activities are mainly acquiring new firms, entering new markets, especially in Asia, with special attention paid to China. Internationalization for the luxury goods company is something natural, but more attention is paid to details such as shop location, the interior design of the shops, the customization of products and adjusting them to local market needs. The goal of this article is to briefly present the internationalization phenomenon and show it on the example of LVMH on the Asian market, with special attention paid to the Chinese luxury market. The main research methods used for this article are a literature study and a case study.

Keywords: internationalization, international business, LVMH, luxury goods market 


\section{Streszczenie}

\section{Proces internacjonalizacji firmy na przykładzie LVMH}

Proces internacjonalizacji jest często stosowany przez firmy chcące zwiększyć obszar działalności. Może być rozumiany zarówno jako wejście na nowe rynki za pomocą np. jont-venture, jak i sprzedawanie produktów na rynkach zagranicznych. Istnieją dwa konwencjonalne modele internacjonalizacji: model uppsalski oraz modele oparte na innowacji. Oprócz nich możemy wyróżnić model sieciowy czy też born-global. LVMH jest międzynarodowym konglomeratem dóbr luksusowych, który od początku swojego istnienia wykorzystywał internacjonalizację do wchodzenia na nowe rynki i powiększania zakresu działalności. Teraz aktywność LVMH skupia się głównie na przejmowaniu nowych firm oraz na wchodzeniu na nowe rynki w Azji ze szczególnym uwzględnieniem rynku chińskiego. Dla firm z branży dóbr luksusowych internacjonalizacja jest czymś naturalnym, jednak w przypadku takich firm większy nacisk kładziony jest np. na lokalizację sklepów oraz ich wystrój czy na personalizację produktów, jak również na przystosowanie produktów do potrzeb lokalnego rynku. Artykuł przedstawia pokrótce proces internacjonalizacji na przykładzie LVMH na rynku azjatyckim, ze szczególnym uwzględnieniem chińskiego rynku dóbr luksusowych. Głównymi metodami badań użytymi na potrzeby artykułu są studia literaturowe oraz studium przypadku.

Słowa kluczowe: internacjonalizacja, biznes międzynarodowy, LVMH, rynek dóbr luksusowych

JEL: F23, L29 